\title{
Pengetahuan masyarakat dan pemanfaatan tanaman obat keluarga di desa toya aikmel utara
}

\author{
Muhlisun Azim ${ }^{*}{ }^{1}$, Arief Rafsanjani ${ }^{1}$, Tripuspita Yuliana ${ }^{1}$, Puspawan Hariadi ${ }^{1}$ \\ ${ }^{1}$ Program Studi Farmasi, Fakultas Kesehatan, Universitas Hamzanwadi, Indonesia
}

\begin{tabular}{l}
\hline Article Info \\
\hline Article history: \\
Received Apr $12^{\text {th }}, 2021$ \\
Revised May $20^{\text {th }}, 2021$ \\
Accepted Jun $26^{\text {th }}, 2021$ \\
\hline
\end{tabular}

Keyword:

Family Medicinal Plants

Healthy Living Community

Movement

\begin{abstract}
Family Medicinal Plants (TOGA) is an alternative in achieving GERMAS (Healthy Living Community Movement) as an effort to achieve traditional independent health. The success of the use of TOGA is strongly influenced by the level of public knowledge about the benefits of the type of medicinal plants which has been empirically investigated. The data obtained is qualitative data with descriptive approach analysis method. Data collection was carried out by conducting observations, interviews and technical training to the community in an effort to provide knowledge about TOGA and the creation of a TOGA demonstration plot. The results obtained from this activity are the emergence of public awareness of the use of home yard land for the manufacture of living pharmacies as an effort to achieve independent health and the emergence of public interest in the use of TOGA as a UMKM product in the form of packaged drink sachets as a pilot. The importance of public knowledge about TOGA is needed in supporting the success of achieving independent health and efforts to utilize local biological resources in initiating the manufacture of herbal plant-based UMKM products.
\end{abstract}

(C) 2021 The Authors. Published by IICET.

This is an open access article under the CC BY-NC-SA license

(https://creativecommons.org/licenses/by-nc-sa/4.0

\section{Corresponding Author:}

Azim, M.,

$\doteq$ muhlisun.azim92@gmail.com

\section{Pendahuluan}

Tanaman merupakan tumbuhan yang hidup dimana saja baik di lingkungan rumah, kebun, maupun hutan. Pada dasarnya, tanaman dapat dimanfaatkan sebagai sumber pangan, sandang, dan juga sebagai obat. Dalam kehidupan masyarakat tanaman di manfaatkan sebagai obat untuk pengobatan segala jenis penyakit. Pemanfaatan tanaman sebagai obat sejakk dulu diminati oleh masyarakat desa, hal ini ditandai dengan banyaknya tempat pengobatan tradisional serta banyak beredar produk obat tradisional di tengahtengah masyarakat, yang biasa di sebut herbal (Yulianto, 2017).

Herbal telah menjadi warisan yang telah berlangsung turun temurun sejak dulu. Dengan pengetahuan yang telah diwariskan oleh nenek moyang, hingga sekarang hebal menjadi pilihan masyarakat dalam menyembuhkan penyakit, bahkan ada yang membudidayakan herbal sebagai tanman obat keluarga atau TOGA (Fitri dkk., 2018). Tanaman obat keluarga merupakan tanaman yang dapat dibudidayakan dihalaman rumah sebagai upaya pemanfaatan lahan kosong. Tanaman obat keluarga (TOGA) dimanfaatkan masyarakat sebagai obat, bumbu masakan serta pelengkap pada bahan makanan sebagai sayuran (Sari dkk., 2019). TOGA dapat dijadikan sebagai obat karena memiliki kandungan atau zat aktif yang berfungsi dalam mencegah serta mengobati penyakit, baik itu penyakit yang disebabkan oleh perubahan cuaca maupun penyakit lainnya (Maulidiah dkk., 2020). 
Pengetahuan masyarakat tentang tanaman obat keluarga beserta manfaat dan kegunaannya baik untuk upaya peningkatan kesehatan, mencegah dari penyakit, penyembuhan penyakit dan pemulihan sudah ada sejak zaman dahulu dan sudah digunakan oleh masyarakat luas. Saat ini juga masyarakat mulai menggunakan kembali tanaman obat keluarga untuk kesehatan mereka. WHO (Word Health Organization) merencanakan gaya hidup sehat dengan cara back to nature atau kembali ke alam sebagai tindakan persuasif dalam meningkatkan penggunaan makanan tinggi serat dari tumbuhan, tanpa bahan pengawet, pewarna, perasa, pengembang dan penguat aroma (Wulandari, 2018).

Pengetahuan masyarakat tentang TOGA tanaman obat keluarga yang bermanfaat dalam upaya promotive, preventive, kurative, rehabilitative serta untuk mempercantik diri, sudah dimanfaatkan sejak zaman nenek moyang kita sebelum pengobatan medis modern. Pengethauan ini didapatkan secara turun temurun (Ariani dkk., 2020).

Sebagai Langkah dalam mensukseskan Gerakan Masyarakat Hidup Sehat secara mandiri dapat dimulai dari penyuluhan serta pendataan pengetahuan masyarakat terhadap Tanaman Obat Keluarga yang dapat dituangkan dalam kegiatan pengabdian kepada masyarakat di Desa Toya Kecamatan Aikmel Utara. Kegiatan ini dimaksudkan untuk memberikan pengathuan pada masyarakat Desa Toya tentang tanaman obat keluarga, pada terhadap pentingnya apotik hidup guna mendukung masyarakat sehat secara mandiri, serta memberikan kesadaran masyarakat terhadap pemanfaatan lahan pekarangan rumah dalam memenuhi kebutuhan sehat dengan herbal dan dapur keluarga.

\section{Metode}

Kegiatan pengabdian kepada masyarakat tentang pemanfaatan Tanaman Obat Keluarga (TOGA) yang dilaksanakan oleh tim pengabdian kepada masyarakat Program Studi Farmasi Universitas Hamzanwadi Lombok Timur dilakukan selama 2 minggu mulai $12-26$ Agustus yang dilakuakan dengan metode terstruktur secara sosialisasi dan observasi lapangan melalui Komunikasi Informasi dan Edukasi (KIE). Sosialisasi dilakukan pada pada tanggal 12 agustus dengan tema Terapi dan Efek Samping Obat dengan menghadirkan organisasi Ikatan Apoteker Indonesia Cabang Lombok Timur. Sementara observasi dan KIE dilakukan selama tiga belas hari pada 8 wilayah Desa Toya.

Kegiatan sosialisasi yang dilakukan menggunakan metode presentasi, ceramah dan tanya jawab, serta kegiatan KIE dilakukan dengan mengunjungi langsung dari rumah ke rumah warga untuk menggali informasi dan memberikan informasi terkait TOGA. Metode evaluasi, prosedur pengambilan data dan angket observasi yang digunakan sebagai berikut ini ;

Instrumen Pengumpulan Data

A. Observasi

1. Mengamati secara langsung jenis tanaman yang di manfaatkan masyarakat di Desa Toya.

2. Mengamati secara langsung kegiatan masyarakat di Desa Toya dalam Pemanfaatan Tanaman Obat Keluarga.

3. Mengamati Secara Langsung Ketersedian Tanaman Tersebut di Desa Toya

B. Wawancara

1. Apa yang anda ketahui tentang Tanaman Obat Keluarga?

2. Jenis Tanaman Obat apa saja yang anda gunakan?

3. Dari mana anda memperoleh Tanaman Obat tersebut?

4. Dari mana anda memperoleh pengetahuan tentang TOGA?

5. Menurut anda Jenis Tanaman Obat apa saja yang bisa dijadikan bahan Obat-obatan?

6. Bagaimana cara mengolah Tanaman Obat tersebut?

7. Menurut anda apakah Tanaman Obat Keluarga sangat dibutuhkan oleh masyarakat di Desa Toya sebagai bahan obat?

8. Menurut anda adakah pengetahuan tentang Pemanfaatan Tanaman Obat Keluarga yang diwariskan secara turun-temurun di Desa Toya?

9. Bagian apa saja yang di gunakan untuk pemanfaatan Tanaman Obat Keluarga?

10. Bagaimana cara pengolahan dan penggunaan TOGA yang telah anda lakukan?

11. Bagaimana khasiat yang anda rasakan dari mengonsumsi TOGA tersebut?

12. Apa yang anda rasakan jika mengonsumsi TOGA tersebut dalam dosis berlebihan?

13. Selain untuk obat untuk apa saja Tanaman Obat Keluarga dimanfaatkan? 


\section{Kegiatan TOGA}

1. Bersama Masyarakat melakukan Persiapan Tempat TOGA

2. Bersama Masyarakat Melakukan Kegiatan Pengolahan TOGA dalam bentuk Rebusan (diminum)

3. Bersama Masyarakat Melakukan Kegiatan Pengolahan TOGA dalam bentuk Serbuk Simplisia

4. Bersama Masyarakat Melakukan Kegiatan Packing TOGA dalam bentuk Serbuk Simplisia.

5. Bersama Masyarakat Melakukan Mendesain Nama dan Kemasan hasil Serbuk TOGA.

\section{Hasil dan Pembahasan}

Hasil

Kegiatan KIE (komunikasi, informasi dan edukasi) mengenai Terapi Efek Samping Obat serta pemanfaatan Tanaman Obat Keluarga (TOGA) dilakuan 1 hari, kegiatan yang dilakukan di kantor Desa Toya dengan peserta mencapai 50 orang yang menghadirkan semua kader PKK dan kepala wilayah Desa Toya. Kegiatan ini memberikan edukasi dan informasi terkait bagaimana menggunakan obat yang baik dan benar serta melakukan kegiatan DAGUSIBU (Dapatkan Gunakan Simpan dan Buang) serta meanfaatkan obat-batan tradisional dalam memenuhi kebutuhan sehat.

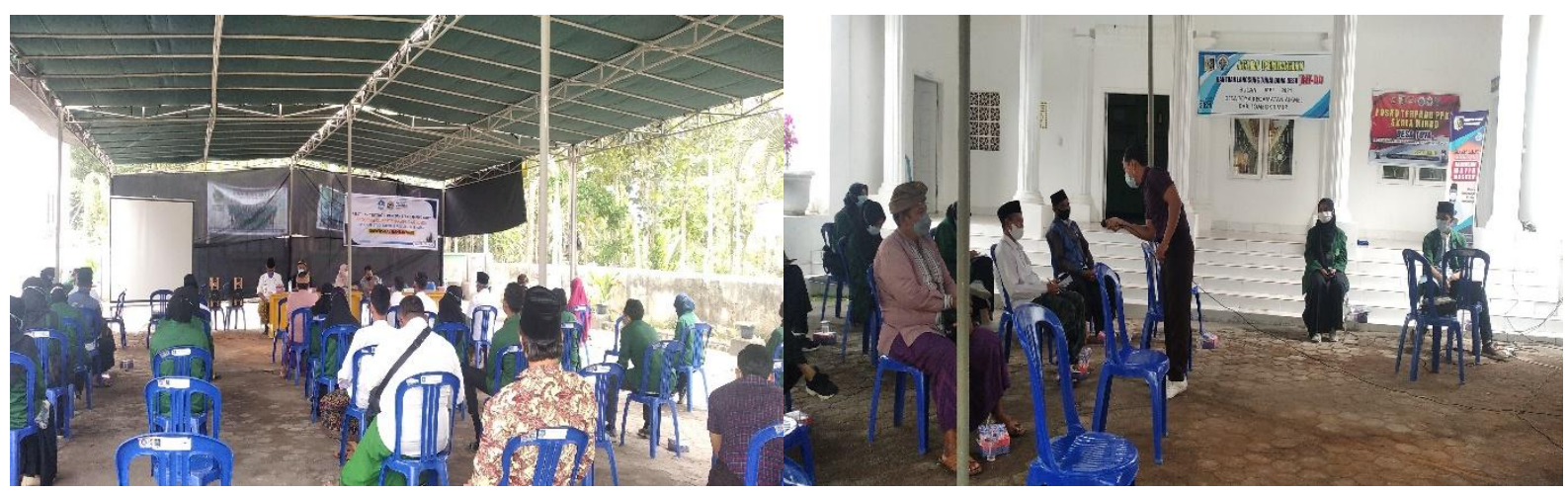

Gambar 1. Kegiatan KIE TOGA dan Terapi Efek Samping Obat

Selanjutnya hasil kegiatan sosialisasi yang dilakukan, masyarakat diberikan edukasi dan penyuluhan dari rumah kerumah untuk KIE secara langsung terkait TOGA serta memberikan percontohan pembuatan apotek hidup dalam pemanfaatan lahan kosong untuk memenuhi Kesehatan mandiri keluarga. Selain apotek hidup sebagai percontohan TOGA, tim Pelaksana pengabdian kepada masyarakat juga memberikan percontohan hasil pengolahan TOGA yang berasal dari sumber lokal yaitu Jahe, kunyit dan gula aren yang disingkat JAKUREN sebagai prototype pada masyarakat untuk tergerak dalam mengembangkan produk UMKM berbahan dasar tanaman obat.

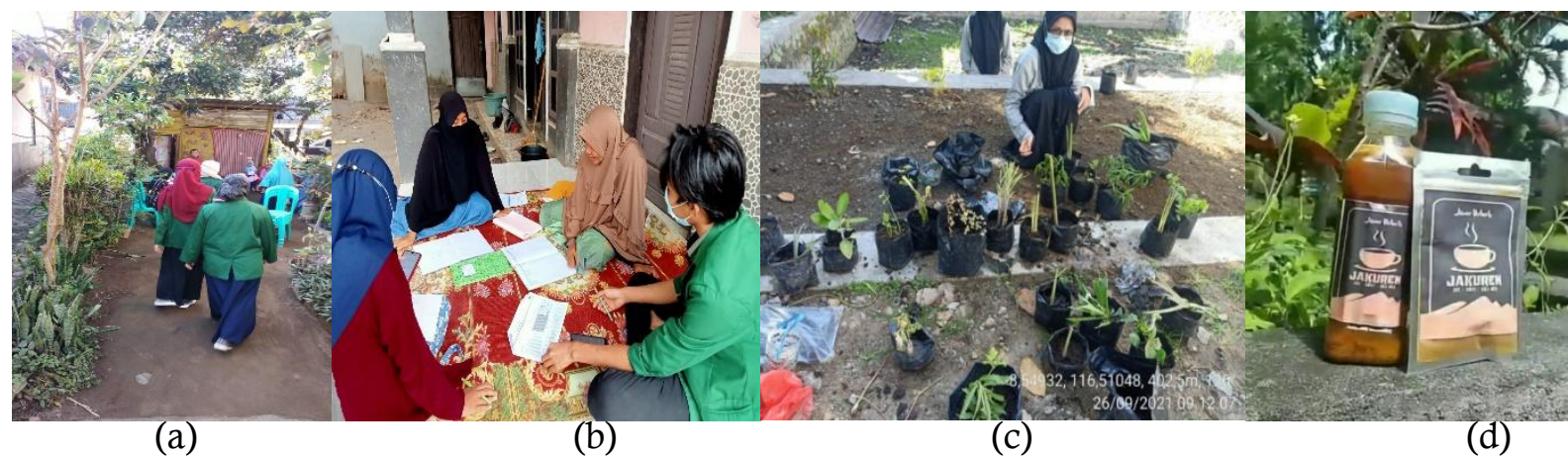

Gambar 2. (a) Observasi lapangan (b) KIE TOGA secara langsung (c) Percontohan apotek hidup (d) Percontohan produk herbal JKUREN 
Hasil wawancara kegiatan KIE secara langsung dari rumah keruah menghasilkan ada 34 responden yang memahami tentang pemanfaatan TOGA namun belum melakukan penanaman TOGA dipekarangan rumah secara mandiri. Kegiatan KIE yang dilakukan pada 8 wilayah Desa Toya yakni dusun Toya Daya, Toya Lauq, Al-Muttaqin, Darul Ihsan, Pertemuan, Sampet, Kuang Gorong dan dusun Akar. Berikut hasil KIE pada masyarakat di dusun-dusun tersebut

Tabel 2. Hasil KIE tentang TOGA dan Pemanfaatannya

\begin{tabular}{|c|c|c|c|c|c|}
\hline Nama & NIK & Usia & $\begin{array}{c}\text { Nama dan } \\
\text { bagian tanaman } \\
\text { yang } \\
\text { digunakan }\end{array}$ & Cara pengolahan & $\begin{array}{l}\text { Manfaat/ } \\
\text { Khasiat }\end{array}$ \\
\hline Riska Savitri & $\begin{array}{c}520309 \mathrm{xxxx} \\
\mathrm{xxxxxx}\end{array}$ & 22 th & Daun Mint & $\begin{array}{l}\text { Daun yang diambil } \\
\text { kemudian di campurkan } \\
\text { pada bak air yang } \\
\text { digunakan man di }\end{array}$ & $\begin{array}{l}\text { Menyegarka } \\
\mathrm{n} \text { tubuh } \\
\text { setelah } \\
\text { beraktifitas }\end{array}$ \\
\hline Ika Purnawati & $\begin{array}{c}520309 \mathrm{xxxx} \\
\mathrm{xxxxxx}\end{array}$ & 19th & Daun Pegagan & $\begin{array}{l}\text { Diambil daun yang sudah } \\
\text { dicuci lalu di tumbuk } \\
\text { halus dan dibuat salep }\end{array}$ & $\begin{array}{l}\text { Untuk } \\
\text { Mengobati } \\
\text { Luka }\end{array}$ \\
\hline Hindun & $\begin{array}{c}5230946776 \\
0006\end{array}$ & 44th & $\begin{array}{l}\text { Rimpang } \\
\text { kunyit,rimpang } \\
\text { jahe,rimpang } \\
\text { jahe } \\
\text { merah,rimpang } \\
\text { serai,buah cabe } \\
\text { jawa,rimpang } \\
\text { temulawak,biji } \\
\text { jintan hitam }\end{array}$ & $\begin{array}{l}\text { Kunyit dihaluskan } \\
\text { kemudian diambil air nya } \\
\text { dan dicampur dengan } \\
\text { bahan yang ada. }\end{array}$ & $\begin{array}{l}\text { Meningkatk } \\
\text { an daya } \\
\text { tahan tubuh }\end{array}$ \\
\hline Megawati & $\begin{array}{c}520309 \mathrm{xxxx} \\
\mathrm{xxxxxx}\end{array}$ & 26th & $\begin{array}{l}\text { Rimpang } \\
\text { serai.rimpang } \\
\text { lengkuas,rimpan } \\
\text { g temulawak }\end{array}$ & Direbus & $\begin{array}{l}\text { Untuk daya } \\
\text { tahan tubuh }\end{array}$ \\
\hline Isniawati & $\begin{array}{c}520309 \mathrm{xxxx} \\
\mathrm{xxxxxx}\end{array}$ & 30 th & $\begin{array}{l}\text { Rimpang } \\
\text { kunyit,rimpang } \\
\text { jahe,buah } \\
\text { lemon,rimpang } \\
\text { serai,biji } \\
\text { ketumbarkayu } \\
\text { manis,biji } \\
\text { kapulaga,bunga } \\
\text { cengkeh,buah } \\
\text { asam jawa }\end{array}$ & $\begin{array}{l}\text { 1.Rimpang } \\
\text { kunyit,rimpang } \\
\text { serai,rimpang jahe, } \\
\text { direbus } \\
\text { 2.Ketumbar,kayu } \\
\text { manis,kapulaga,cengkeh } \\
\text { direbus } \\
\text { 3.Asam jawa direbus }\end{array}$ & $\begin{array}{l}\text { 1.Meningka } \\
\text { tkan daya } \\
\text { tahan tubuh } \\
\text { 2.Detoks } \\
\text { 3.Pelangsin } \\
\text { g }\end{array}$ \\
\hline Sopiah & $\begin{array}{c}520309 \mathrm{xxxx} \\
\mathrm{xxxxxx}\end{array}$ & 30 th & $\begin{array}{l}\text { Rimpang } \\
\text { kunyit,rimpang } \\
\text { temulawak,rimp } \\
\text { ang } \\
\text { serai,rimpang } \\
\text { jahe }\end{array}$ & Direbus & $\begin{array}{l}\text { Meningkatk } \\
\text { an daya } \\
\text { tahan tubuh }\end{array}$ \\
\hline $\begin{array}{l}\text { Musyadad } \\
\text { akbar }\end{array}$ & $\begin{array}{c}520309 \times x x x \\
\text { XXXXXx }\end{array}$ & 35 th & $\begin{array}{l}\text { Rimpang } \\
\text { jahe,rimpang } \\
\text { temulawak, daun } \\
\text { banten }\end{array}$ & $\begin{array}{l}\text { 1.Rimpang } \\
\text { jahe,temulawak direbus } \\
\text { 2.Daun banten } \\
\text { dihaluskan }\end{array}$ & $\begin{array}{l}\text { 1.penghang } \\
\text { at tubuh } \\
2 . \text { sebagai } \\
\text { antiseptik } \\
\text { dan } \\
\text { meringanka } \\
\text { n demam } \\
\text { pada anak- } \\
\text { anak }\end{array}$ \\
\hline
\end{tabular}




\begin{tabular}{|c|c|c|c|c|c|}
\hline Nama & NIK & Usia & $\begin{array}{l}\text { Nama dan } \\
\text { bagian tanaman } \\
\text { yang } \\
\text { digunakan }\end{array}$ & Cara pengolahan & $\begin{array}{l}\text { Manfaat/ } \\
\text { Khasiat }\end{array}$ \\
\hline Tohri & $\begin{array}{l}\text { 520309xxxx } \\
\text { xxxxxx }\end{array}$ & 48th & $\begin{array}{l}\text { Rimpang } \\
\text { kunyit,batang } \\
\text { ginseng }\end{array}$ & Direbus & $\begin{array}{l}\text { Luka } \\
\text { dalam, hiper } \\
\text { tensi }\end{array}$ \\
\hline Juliati & $\begin{array}{c}5203094102 \\
980842\end{array}$ & 22th & $\begin{array}{l}\text { Rimpang } \\
\text { serai,gula merah }\end{array}$ & Dibuat jamu & $\begin{array}{l}\text { Perawatan } \\
\text { setelah } \\
\text { bersalin }\end{array}$ \\
\hline Misnawati & $\begin{array}{c}5203036010 \\
210001\end{array}$ & 19th & $\begin{array}{l}\text { Rimpang } \\
\text { kunyit,rimpang } \\
\text { serai,rimpang } \\
\text { temulawak,biji } \\
\text { lada }\end{array}$ & Dibuat jamu & $\begin{array}{l}\text { Untuk } \\
\text { penyembuh } \\
\text { an kista }\end{array}$ \\
\hline Ainun & $\begin{array}{l}520309 \mathrm{xxxx} \\
\quad \mathrm{xxxxxx}\end{array}$ & 30th & $\begin{array}{l}\text { Rimpang } \\
\text { kunyit,biji sang }\end{array}$ & $\begin{array}{l}\text { Dihaluskan dan } \\
\text { dicampur gula merah }\end{array}$ & $\begin{array}{l}\text { Perawatan } \\
\text { setelah } \\
\text { bersalin }\end{array}$ \\
\hline Sopiah & $\begin{array}{l}5203095303 \\
800005\end{array}$ & 42th & Getah kelor & $\begin{array}{l}\text { Dicampur dengan garam } \\
\text { halus }\end{array}$ & $\begin{array}{l}\text { Untuk } \\
\text { meringanka } \\
\text { n sakit gigi }\end{array}$ \\
\hline Isnain & $\begin{array}{c}5203094107 \\
921102\end{array}$ & 27th & & dioles & Untuk luka \\
\hline Siti Aminah & $\begin{array}{l}5203094712 \\
920002\end{array}$ & 35 th & $\begin{array}{l}\text { Daun } \\
\text { kecipir,daun } \\
\text { pandan }\end{array}$ & Direbus & $\begin{array}{l}\text { Meringanka } \\
\text { n sakit } \\
\text { gigi(dikumu } \\
\text { r) }\end{array}$ \\
\hline Fathul Sa'diah & $\begin{array}{l}5203096008 \\
940004\end{array}$ & 27 th & $\begin{array}{l}\text { Daun jarak,daun } \\
\text { sirsak,buah } \\
\text { jambu biji } \\
\text { muda,daun } \\
\text { sirih,daun } \\
\text { alpukat,daun } \\
\text { sambiloto,rimpa } \\
\text { ng kunyit }\end{array}$ & $\begin{array}{l}\text { 1.Daun jarak ditumbuk } \\
\text { airnya diminum } \\
\text { 2.Daun sirsak ditambah } \\
\text { bawah merah ditumbuk } \\
\text { 3.Buah jambu biji muda } \\
\text { dimakan langsung } \\
\text { 4.Daun sirih direbus, air } \\
\text { rebusan diminum } \\
\text { 5.Daun Alpukat direbus } \\
\text { 6.Daun Sambiloto } \\
\text { direbus } \\
\text { 7.Rimpang } \\
\text { Kunyit }\end{array}$ & $\begin{array}{l}\text { 1.Selesma } \\
\text { 2.Meringan } \\
\text { kan demam } \\
\text { 3.Untuk } \\
\text { diare } \\
\text { 4.Keputihan } \\
\text { 5.Hipertensi } \\
\text { 6.Meningka } \\
\text { t kan tenaga } \\
\text { 7.Memudar } \\
\text { kan bekas } \\
\text { luka }\end{array}$ \\
\hline Inaq Jul & $\begin{array}{l}520309 \mathrm{xxxx} \\
\quad \mathrm{xxxxxx}\end{array}$ & 47 th & Daun Kersen & Direbus & $\begin{array}{l}\text { Menurunka } \\
\mathrm{n} \text { kadar gula }\end{array}$ \\
\hline Abdul Hayyi & $\begin{array}{l}520309 \mathrm{xxxx} \\
\quad \mathrm{xxxxxx}\end{array}$ & 45th & $\begin{array}{l}\text { Daun } \\
\text { Pegagan,daun } \\
\text { bawang putih }\end{array}$ & $\begin{array}{l}\text { 1.Daun pegagan } \\
\text { ditumbuk } \\
\text { 2.daun bawang putih } \\
\text { direbus dan ditumbuk }\end{array}$ & $\begin{array}{l}\text { 1.meredaka } \\
\text { n luka } \\
\text { 2.panas } \\
\text { dalam(direb } \\
\text { us), nyeri(tu } \\
\text { mbuk) }\end{array}$ \\
\hline Inaq Epol & $\begin{array}{l}520309 \mathrm{xxxx} \\
\quad \mathrm{xxxxxx}\end{array}$ & 45th & $\begin{array}{l}\text { Daun } \\
\text { sirih,rimpang } \\
\text { kunyit,rimpang } \\
\text { jahe,gula merah }\end{array}$ & Ditumbuk lalu direbus & $\begin{array}{l}\text { Memulihka } \\
\mathrm{n} \text { tenaga }\end{array}$ \\
\hline Ely suryani & 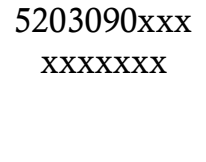 & 25th & $\begin{array}{l}\text { Rimpang } \\
\text { kencur,rimpang } \\
\text { jahe,rimpang } \\
\text { temulawak }\end{array}$ & Dibuat jadi jamu & $\begin{array}{l}\text { Menambah } \\
\text { imun tubuh }\end{array}$ \\
\hline Elisa Sopia & $\begin{array}{c}520309 \mathrm{xxxx} \\
\mathrm{xxxx} \\
\end{array}$ & 27th & Daun kemangi & $\begin{array}{l}\text { Ditumbuk,airnya } \\
\text { diminum }\end{array}$ & Demam \\
\hline
\end{tabular}




\begin{tabular}{|c|c|c|c|c|c|}
\hline Nama & NIK & Usia & $\begin{array}{l}\text { Nama dan } \\
\text { bagian tanaman } \\
\text { yang } \\
\text { digunakan }\end{array}$ & Cara pengolahan & $\begin{array}{l}\text { Manfaat/ } \\
\text { Khasiat }\end{array}$ \\
\hline Nurliana & $\begin{array}{c}520309 \times x x x \\
\quad x \times x x x x\end{array}$ & 28th & Daun jambu biji & Direbus & Untuk diare \\
\hline Nurhidayati & $\begin{array}{c}520309 \times x x x \\
\text { xxxxxx }\end{array}$ & 30 th & Daun alpukat & $\begin{array}{l}\text { Direbus, kemudian air } \\
\text { rebusan itu digunakan } \\
\text { untuk merendam diri }\end{array}$ & Gatal-gatal \\
\hline Hartini & $\begin{array}{c}520309 \mathrm{xxxx} \\
\mathrm{xxxxxx}\end{array}$ & 32 th & $\begin{array}{l}\text { Daun } \\
\text { sirsak,daun } \\
\text { pepaya,bunga } \\
\text { pepaya,rimpang } \\
\text { kunyit,rimpang } \\
\text { jahe,jeruk } \\
\text { nipis,biji merica }\end{array}$ & $\begin{array}{l}\text { 1.Daun Sirsak direbus } \\
\text { 2.Daun pepaya,bunga } \\
\text { pepaya direbus } \\
\text { 3.Rimpang } \\
\text { kunyit,rimpang } \\
\text { jahe,merica,dan gula } \\
\text { merah dibuat jamu }\end{array}$ & $\begin{array}{l}\text { 1.Hipertensi } \\
\text { 2.Hipertensi } \\
\text { 3.Meningka } \\
\text { tkan imun } \\
\text { tubuh,dema } \\
\text { m,setelah } \\
\text { persalinan }\end{array}$ \\
\hline Muliah & $\begin{array}{c}5203094412 \\
700002\end{array}$ & 64 th & $\begin{array}{l}\text { Rimpang } \\
\text { kunyit,rimpang } \\
\text { lengkuas,bawang } \\
\text { putih }\end{array}$ & Direbus & $\begin{array}{l}\text { Meningkatk } \\
\text { an imun }\end{array}$ \\
\hline Inaq.Muhri & $\begin{array}{c}520309 x x x x \\
\text { xxxxxx }\end{array}$ & 70th & $\begin{array}{l}\text { Daun } \\
\text { turi,rimpang jahe }\end{array}$ & Direbus & $\begin{array}{l}\text { Demam dan } \\
\text { sakit } \\
\text { pinggang }\end{array}$ \\
\hline Marfu'atun & $\begin{array}{c}520309 \times x x x \\
\text { xxxxxx }\end{array}$ & 40th & $\begin{array}{l}\text { Rimpang } \\
\text { jahe,rimpang } \\
\text { serai,daun } \\
\text { mahkota } \\
\text { dewa,jeruk nipis }\end{array}$ & Direbus & $\begin{array}{l}\text { Sakit } \\
\text { pinggang } \\
\text { dan } \\
\text { meningkatk } \\
\text { an imun } \\
\text { tubuh }\end{array}$ \\
\hline Zaihari & 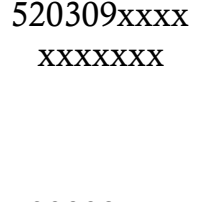 & 40th & $\begin{array}{l}\text { Jahe, daun } \\
\text { sukun,rimpang } \\
\text { kunyit,daun } \\
\text { sager }\end{array}$ & $\begin{array}{l}\text { 1.rimpang jahe,daun } \\
\text { sukun dan kunyit direbus } \\
\text { 2.daun sager } \\
\text { digiling,diremas airnya } \\
\text { diambil atau bisa direbus }\end{array}$ & $\begin{array}{l}\text { 1.Nyeri } \\
\text { lutut } \\
\text { 2.Demam }\end{array}$ \\
\hline Maesarah & $\begin{array}{c}520309 x x x x \\
\text { xxxxx }\end{array}$ & 45 th & $\begin{array}{l}\text { Jahe,sang,jinten, } \\
\text { cengkeh,kapulag } \\
\text { a,singasari }\end{array}$ & Tumbuk & Nyeri \\
\hline IQ.Nurul Aini & $\begin{array}{c}520309 x x x x \\
\text { xxxxx }\end{array}$ & 40th & $\begin{array}{l}\text { Daun } \\
\text { pepaya,daun } \\
\text { sirsak, kulit kayu } \\
\text { kelapa,daun } \\
\text { sukun,daun } \\
\text { jambu biji }\end{array}$ & $\begin{array}{l}\text { 1.daun pepaya,daun } \\
\text { sirsak dimasak } \\
\text { 2.kulit kayu kelapa } \\
\text { dimasak } \\
\text { 3.daun jambu biji } \\
\text { dimasak } \\
\text { 4.daun pandan dimasak }\end{array}$ & $\begin{array}{l}\text { 1.demam } \\
\text { 2.menamba } \\
\text { h tenaga } \\
\text { 3.untuk } \\
\text { diare } \\
\text { 4.untuk } \\
\text { diabetes }\end{array}$ \\
\hline Iq.Bilal & $\begin{array}{c}520309 x x x x \\
\text { XXXXx }\end{array}$ & 35 th & Daun Alpukat & Dimasak & $\begin{array}{l}\text { Darah } \\
\text { tinggi }\end{array}$ \\
\hline Sahdah & $\begin{array}{c}520309 \times x x x \\
\text { xxxxxx }\end{array}$ & 40th & $\begin{array}{l}\text { Daun } \\
\text { binahong,daun } \\
\text { sirsak }\end{array}$ & Direbus & $\begin{array}{l}\text { Panas } \\
\text { dalam }\end{array}$ \\
\hline Suriah & $\begin{array}{c}520309 x x x x \\
\text { xxxxx }\end{array}$ & 40th & $\begin{array}{l}\text { Daun } \\
\text { sager,tapak kuda }\end{array}$ & Direbus & $\begin{array}{l}\text { Panas } \\
\text { dalam }\end{array}$ \\
\hline Nursafika & $\begin{array}{c}520309 \mathrm{xxxx} \\
\mathrm{xxxxxx}\end{array}$ & 25 th & $\begin{array}{l}\text { Bawang merah } \\
\text { dan minyak telon }\end{array}$ & Dioles & Demam \\
\hline Zahratul aini & $\begin{array}{c}520309 \times x x x \\
\text { xxxxxx } \\
\end{array}$ & 27 th & Bawang putih & $\begin{array}{l}\text { Dihaluskan (dihirup } \\
\text { aromanya) }\end{array}$ & Batuk \\
\hline
\end{tabular}


Keterangan : No KTP yang tidak lengkap dicantumkan karena warga menolak untuk memebrikan no NIK

Tabel diatas dapat menggambarkan bahwa masyarakat lebih memahami tentang TOGA banyak dari klasifikasi bumbu-bumbu dapur, sehingga pada dasarnya TOGA bukan hanya untuk terapi tetapi juga untuk pelengkap rasa pada kuliner lokal.

\section{Pembahasan}

Pelaksanaan pengabdian kepada masyarakat ini merupakan indikator capaian kinerja utama dalam Program Kompetisi Kampus Merdeka (PKKM). Pengabdian masyarakat dilakukan di Desa Toya karena beberapa hal pertimbangan, bahwa des aini merupakan desaya yang memiliki cukup banyak permasalahan yang harus dituntaskan. Desa Toya ini sebagai dosa yang berada dekat dengan kaki Gunung Rinjani merupakan lokasi yang strategis jika ingin mengembangkan Apotek Hidup. Letak geografis yang baik dan kondisi tanah yang subur memberikan peluang besar dalam penerapan apotek hidup salah satunya TOGA sebagai Langkah untuk mencapai Gerakan Masyarakat Hidup Sehat (GERMAS) Mandiri. Apotek hidup yang telah dibuat bersama dengan masyarkat merupakan sebagai langkah serius dalam pembudidayaan dan pemanfaatan tanaman herbal sebagai langkah untuk menuju sehat secara mandiri.

Selanjutnya dari hasil observasi dan KIE yang dilakukan bahwa tanaman-tanaman yang disebutkan olrh warga Desa Toya memeang telah tercatat secara empiris memiliki kandungan zat aktif yang dapat memberikan efek penyembuhan. Beberapa diantaranya yaitu jahe, kunyit, temulawak, lengkuas, binahong, pegagan, sambiloto, daun jambu biji. Beberapa diataranya merupakan tanaman herbal yang telah tercatat dalam panduan formularium obat herbal Indonesia dalam peraturan Menteri Kesehatan republik Indonesia Nomor 6 Tahun 2016 tentang Formularium Obat Herbal Asli Indonesia. Tanamantanaman tersebut dibuat dalam bentuk serbuk simplisia lalu diminum dengan air hangat.

Program pengabdian masyarakat ini memberikan hasil yang positif kepada masyarakat Desa Toya mulai dari proses sosialisasi tentang terapi efek samping obat serta edukasi tentang TOGA. Antusias masyarakat terlihat dari banyaknya masyrakat yang hadir pada saat kegiatan sosialisasi. Kegiatan sosialisasi yang dilakukan memberikan dampak positif bagi warga karena masyarakat mendapatkan informasi yang bermanfaat terkait DAGUSIBU obat serta pemanfaatan tanaman herbal untuk Kesehatan mandiri keluarga.

Selanjutnya melalui hasil obeservasi dan KIE tentang TOGA, masyarakat diberikan pandangan tentang inovasi dalam membuat suatu produk hasil olahan TOGA yang dibuat dalam bentuk kemasan jamu sebagai bagian dari langkah menumbuhkan minat masyarakat dalam UMKM obat tradisional. Adanya produk prototype olahan jamu JAKUREN memberikan kesadaran kepada masyarakat bahwa disekitar lingkungan mereka banyak tanaman yang dapat dijadikan sebagai produk herbal untuk meningkatkan jumlah produk UMKM Desa Toya sebagai langkah meningkatkan pendapatan perkapita Desa Toya serta membuka lapangan kerja bagi masyarakat Desa Toya melalui kegiatan usaha Bersama dengan BUMD.

\section{Simpulan}

Kegiatan pengabdian kepada masyarakat ini belangsung dengan baik dan lancer, karena aparat dan masyarakat desa dapat bekerja sama dengan baik. Namun dari kegiatan yang telah dilakukan memang belum dilakukan evaluasi secara terstruktur dari kegiatan ini, akan tetapi kegiatan pengabdian ini akan terus dilakukan pada tahun berikutnya karena program kompetisi kampus merdeka merupakan program yang berkelanjutan. Secara garis besar kegiatan yang telah dilakukan memberikan dampak nyata bagi masyarakat desa terutama setelah diberikan beberapa prototype berupa apotek hidup untuk TOGA dan produk herbal JKUREN yang dapat menumbuhkan minat masyarakat desa dalam mengembangkan UMKM.

\section{Acknowledgements}

Terima kasih kami ucapkan kepada Kepala Desa Toya, Kecamatan Aikmel Utara, Kabupaten Lombok Timur yang telah mendukung secara penuh program pengabdian ini dengan support segala fasilitasnya dan Kerjasama yang baik dengan melibatkan semua pihak pemerintah kabupaten mulai dari dinas Kesehatan Kabupaten dan Puskesmas Kecamatan Aikmel Utara. Ucapan terimakasih sebesarbesarnya juga kami ucapkan kepada Kementerian Pendidikan dan Kebudayaan yang telah memberikan 
hibah Program Kompetisi Kampus Merdeka (PKKM) dengan pendanaan penuh yang bersumber dari program tersebut.

\section{Referensi}

Ariani, L., Miftahurrohmah, N., \& Winarti, W. (2020). Peningkatan Pengetahuan tentang Tanaman Obat Keluarga kepada Siswa Sekolah Dasar melalui Konseling, Flash Card, dan Berkebun Bersama. Jurnal Pengabdian Kepada Masyarakat (Indonesian Journal of Community Engagement), 6(1), 63. https://doi.org/10.22146/jpkm.52576

Fitri, R., Oktiarni, D., \& Arso, D. D. (2018). Eksplorasi Pengetahuan Obat Tradisional dalam Prespektif Hukum Kekayaan Intelektual di Bengkulu. Mimbar Hukum - Fakultas Hukum Universitas Gadjah Mada, 30(2), 304. https://doi.org/10.22146/jmh.31021

Maulidiah, M., Winandari, O. P., \& Saputri, D. A. (2020). Pemanfaatan Organ Tumbuhan sebagai Obat yang Diolah Secara Tradisional Di Kecamatan Kebun Tebu Kabupaten Lampung Barat. Jurnal Ilmu Kedokteran Dan Kesehatan, 7(2), 73-91. https://doi.org/10.33024/jikk.v7i2.2720

Menteri Kesehatan Republik Indonesia. 2016. Peraturan Menteri Kesehatan Republik Indonesia Nomor 6 Tahun 2016 Tentang Formularium Obat Herbal Asli Indonesia. Direktur Jenderal Peraturan Perundang-Undangan Kementerian Hukum dan Hak Asasi Manusia Republik Indonesia.

Siska Mayang Sari, Ennimay, \& Tengku, A. R. (2019). Pemanfaatan Tanaman Obat Keluarga (TOGA) Pada Masyarakat. Dinamisia: Jurnal Pengabdian Kepada Masyarakat, 3, 1-7. https://doi.org/10.31849/dinamisia.v3i2.2833

Wulandari, R. L. (2018). Pemanfaatan Tanaman Obat Keluarga (TOGA) untuk Pengobatan Diabetes Melitus. Abdimas Unwahas, 3(1), 30-32. https://doi.org/10.31942/abd.v3i1.2235

Yulianto, S. (2017). Penggunaan Tanaman Herbal Untuk Kesehatan. Jurnal Kebidanan Dan Kesehatan Tradisional, 2(1), 1-7. https://doi.org/10.37341/jkkt.v2i1.37 